\title{
Space, Body, and the Notion of Boundary: A Category-Theoretical Approach to Religion
}

\author{
VEIKKO ANTTONEN \\ University of Turku
}

\begin{abstract}
In the article the issue of sacrality is explored from the points of view of cultural anthropology and cognitive science of religion. Culturespecific contents of meaning bestowed on the notion of "sacred" are not approached as religious representations in which some theologically defined agent, metaphysical entity or otherworldly level of existence is believed to manifest itself to human beings. Instead, various attributions of sacrality are explored as representations of the general mental capacity of human beings to set apart places and sites in specific locations and points of terrain in local topography in order to mark ritual spaces and establish rules of conduct for their maintenance as well as for specific social values and categorizations on which the inviolability of behavioral norms is based.
\end{abstract}

\section{The Relevance of the "Sacred" for the Study of Religion}

Comparative religion has done a great service to the growth of scientific knowledge on issues specific to the category of religion in various geographical and cultural contexts in the world. The purpose and significance of the discipline in modern universities does not, however, lie only in the competence of its practitioners to obtain reliable, accurate and empirically valid information on variegated forms of religious representations in cultures the world over. I cannot help emphasizing the role of anthropology of religion with its ethnographic focus on acquiring information on religious beliefs and practices as they are generated in the course of everyday social life, whether in traditional, Modern, or Late Modern societies. Contrary to 
the concerns of theologians and philosophers, scholars of comparative religion register and document religious behavior in the actual social context in which people generate them. Methodologically speaking, the main test of the competence of scholars of religion lies in our ability to locate religion within the frame of a wider socio-cultural and political matrix. Thus, the task of the academic study of religion lies not only in explaining, interpreting and translating theological or mythological contents of religious traditions and worldviews, but most specifically, in relating religious notions to the social world at large (see Smith 2004). In present-day scholarship, new pathways to knowledge have been cleared in which religion is approached as an important arena for displaying general mechanisms of human cognition. By studying religious representations we can explore the ways in which the human mind works (see Boyer 2001; Guthrie 1995; Pyysiäinen 2001). Religion provides a royal road to explore mechanisms by which members of societies and communities represent their social categorizations to themselves. One formative theorist who presaged cognitive questions on religious issues by paying attention to the human capacity to categorize was Émile Durkheim. According to Durkheim, a scholar of religion needs to relate religion to the impure and contagious social world in which its systematic idealizations are composed (see Durkheim 1995). It was Durkheim who suggested that one can find basic social categorizations in religion and that it is through religious cosmologies that people represent their society to themselves. The sine qua non of the study of religion is thus, not only religion, but also the poetics and politics of society.

The notion of the "sacred" has definitely been one of the most important concepts but also one of the most controversial and heavily disputed concepts in the academic study of religion. The basic issue concerns its reference, but just as well its semantics. The word has its history in most of the languages that people speak in the world. We call these object languages. The word "sacred" is used both as a noun and as an adjective in multiple connections with multiple meanings and side-meanings, i.e. denotations and connotations. The semantic history of the notion makes it obvious that 
the average language user does not by the word "sacred" refer only to the domain of religion, but to the domain of commonplaceness, the domain of profanity, that which is part of everyday social life. As scholars of religion, we need to determine the relevance of object language words and concepts and see whether they also do good work as scholarly categories. The history of scholarship indicates that there are various methodological camps, in which the applicability of the "sacred" as a scholarly concept in the study of religion is assessed on varying grounds. Some hold a positive methodological attitude towards its use, while others are categorically negative. The dividing line between scholars lies in their position concerning reductionist and non-reductionist, subjectivist and objectivist methodology. The discrepancy between these two positions with reference to the category of the "sacred" has prevailed in the study of religion since the times of W. Robertson Smith, Émile Durkheim, Nathan Söderblom and Rudolf Otto. In the dispute, theistic and non-theistic presupposions play a key role. Some postulate the importance of the "sacred" to the presupposition that the word and the concept in human language and history is generated in the first place by the intervention of God in the consciousness of human beings and their awareness of external conditions that give rise to questions concerning the nature of life in general and their subjective existence in particular. Recurrent phenomena in religious traditions the world over are taken to prove the contingency of sacrality on the universalistic distribution of God-concepts. Other scholars do not need the notion of super-human agency, but explain cross-cultural regularities on the basis of knowledge regarding the human capacity to categorize put forth by the natural and social sciences as well as arts and humanities. Non-religious interpretations, which do not assign the sui generis existence to religious phenomena, do not thwart the idea that human beings see themselves as creative, aesthetic and cognitively fluid in dealing with external and internal knowledge, sensations and experiences.

Durkheim introduced the notion of the "sacred" as an important methodological tool with the help of which symbolic linkages between religion 
and society, as well as between individual and society, can be explored. As a linguistic index in cultures and their lexicon, the word "sacred" was turned into a technical term with the help of which analytical attention could be directed to the workings of culture-specific systems of classification. In the Durkheimian approach to religion, as I personally read its main tenets, the crucial issue concerns the cultural logics on the basis of which we can explain people's perception of properties in certain categories of persons, animals, objects, times, places and locations as a result of which they are conferred a "sacred" status. Durkheim associated the "sacred" with the social. However, in rethinking Durkheim's legacy to the study of religion, the social needs to be connected with the cognitive. In addition to constraints of social origin, there are certain cognitive constraints in information processing, and these cognitive properties - as evolved capacities in humans - have a certain impact on the logic which governs the attribution of things as "sacred", notwithstanding the fact that there are observed cultural variations in the appearance of sacred objects, persons and phenomena. A vast array of ethnographic data testify to the notion that sacrality is not an inherent property in objects, times and places, but is rather the discursive as well as the non-discursive aspect of human cognitive faculties. In opposition to Durkheim, phenomenologists of religion ${ }^{1}$ - with their emphasis on "numen" - detached "sacred" from its social bondage and disentangled religion as a conceptual entity from the world of corporeal human beings. The attempt to anchor the subjective, transcendental experiences of individuals and the meanings that they assign to these experiences as "objective" properties or modalities of the pre-assumed, ontologically distinct realm of the Sacred (comprehended by the notion of Transcendent) has blurred the sound scientific program that Durkheim and his followers established for the study of religion. Rather than granting a special ontological position to human

\footnotetext{
${ }^{1}$ See e.g., Eliade 1959. George Lakoff and Mark Johnson criticize the phenomenological approach for its fictive nature: "The phenomenological person", Lakoff and Johnson write, "who through phenomenological introspection alone can discover everything there is to know about the mind and nature of experience, is a fiction. Although we can have a theory of a vast, rapidly and automatically operating cognitive unconscious, we have no direct conscious access to its operation and therefore to most of our thought." (Lakoff \& Johnson 1999, 5.)
} 
reflections on certain categories of "phenomenon", the cognitive approach sets out from the interplay between the material and the mental. Language, its syntax and semantics, provides an important avenue for scholars of religion to posit explanatory theories of the uses of the word and the concept of "sacred" and the ways in which its variegated contents have materialized in the history of human cognition. My own methodological solution is based on an attempt to look at the issue of sacrality from its local representations in various cultural contexts. My own interest in this category is based on the idea of creating scholarly debate that has its point of departure in the semantic analysis of the terms denoting sacred (emic terms) that are used locally in various languages. For an ethnographer of religion the abstract metaphysical level of conceptualisation needs to be balanced with the knowledge of the culture-specific logic with underlies the use of terms denoting "sacred". We need to pay attention on ethnographic texts in which the terms appear (see Anttonen 1996). The way in which the sacred is used in theological contexts of different religions should be approached with the same methodological attitude, and seen as instances of the specific cultural logic that has directed the formation of religious ideas in specific localities. In this attempt we need to go beyond the category-formation of the phenomenologists of religion.

\section{Semantics from Latin and Greek}

Let's take a brief look at the usages in Latin and Greek. As Emile Benveniste (1973) has shown, the verb sacrificium stands for an entity that is "made sacred" by ritual attachment. The root for the term sacer is *sak- or *sek denoting "to cut", "to set apart" (Lat. secare). Sacralizing specific spaces presupposes a distinction between the areas of sacrum and profanum. Sacrum denotes the space that was set apart for the temple fanum or templum, the root being *tem- "to cut". The area outside the sacrum was pro-fanum (Lat. pro "in front of", "outside of"). The area of the fanum was area sacra that was consecrated (Lat. consecratio) for ritual use and thus also protected from the impurities of everyday social life. The line of demarcation between sacrum 
and profanum was made inviolable by sanctio that is derived from the notion of sanctus meaning a boundary or a fence. Sanctus is a supernatural sanction by which that which is sacer and which contains augustus (power) is protected from violation. Transgressing the boundary, violating the norm, is followed by punishment, poena. The place set apart for fanum was called aedes sacra, meaning the place that was consecrated to God. The temple was domus dei, the house set apart for God. In Greek the area set apart for the temple was témenos that is also derived from the root temno- denoting "to cut". In Greek Antiquity the notion of religion was connected with the specific social obligations within the bounds of témenos and the house (Gr. Naos) in which the God lived. The notion of tà hierá "sacred things" (from the Greek word for sacred hierós), was used for altars (bomós) and sacrificial rituals (hekátómbē) as well as names of towns and place names such as citadels. The Greek notion of hierós was an attribute of Zeus, and as such, an epithet of respect. According to Benveniste, the distinction between hierós and hosiós corresponds to the sacred/profane opposition proposed by Durkheim. (See Benveniste 1973, 452-469.)

Terms and concepts for "sacred" in Latin and in Greek point out the way to approach the issue of sacrality as a category boundary by which normative distinctions are made in the course of everyday social life. That which is set apart becomes established by placing emphasis on behavioral rules at the border zones between metonymically and metaphorically interconnected categories. Ethnographic accounts, folklore genres, as well as religious texts, are pregnant with explicit or implicit references to boundaries of space and territory as well as of human body as prime locations of the discourse of the "sacred". It is these boundary zones that are invested with such properties of the "sacred" as anomaly, transformation or conceptual change. Myths, legends and other genres of oral tradition make use of these strategic means. Rites of passage in Christianity are a case in point. The idea of Jesus as an embodiment of sacrality becomes represented in socially marked events such as in birth and baptismal ritual, in the ritual of confirmation and also in rituals of marriage and death. The marking of all of these events is focused 
on the human body and the transformation that takes place in its social register. Jesus Christ is a culturally established signifier, a conceptual meeting ground that is brought into play when boundaries between the categories of male and female, life and death, pure and impure, left and right, inside and outside of sacralized space, inside and outside of the human body are in transition. The behavioral as well as the linguistic conventions of human societies testify to the notion that the "sacred" is not a property of an object, but a property of a relation ${ }^{2}$. Whatever religio-cultural content we may invest in the category of the "sacred", it is a category of difference as well as a category of contestation.

\section{Theological Reason and Social Categorizations}

Like any other religion, Christianity is a religion of difference and contestation. The process of introducing Christian theology to indigenous cultures provides information on the contestation of antecedent discourses of the "sacred", especially as a spatial category. Let me quote here the archaeologist, Jane Hubert.

Perhaps one of the reasons why archaeologists and developers find it so hard to understand the reactions of indigenous peoples to the desecration of their sacred sites is because within Christian religion it is possible to deconsecrate sacred sites. A church for example, can be deconsecrated, by carrying out of rituals, so that it becomes a secular site, an ordinary building that can then be used for any purpose. (Hubert 1998, 13-14.)

In prehistoric Finland, the word for "sacred" ( $p y h \ddot{a}^{3}$ ) was not a religious notion, but a geographical term which was used at intersections of spatial

\footnotetext{
2 The need to approach the "sacred" as a relative category was emphasized by Arnold van Gennep (1977). Likewise, Roy Rappaport makes a similar point when writing that "sanctity is ultimately a quality of discourse and not of the objects with which that discourse is concerned" (Rappaport 1979, 209).

${ }^{3}$ For us Finns, notwithstanding our Lutheran, Catholic, Greek Orthodox, atheist, agnostic or whatever religious and spiritual convictions, our language provides us with only one word for "sacred": pyhä. Swedish-speaking Finns, of course, have a Swedish term helig which comes from the Germanic heilig (Germ. *hailaga-). The adjective pyhä is a Germanic loanword that was adopted by speakers of the Early Finnic language as püša during the Bronze Age (c. $1500 / 1400$ - 500 B.C.); Jorma Koivulehto has shown that the source of the adjective pyhä is the Proto-Germanic adjective *wiha-, from the root *wik- ("separation", "cutting" >Gothic weihs "consecrated, sacred of separation"). See Koivulehto 1981; Anttonen 1996.
} 
divisions, and as such in transition areas, to mark value-laden sites in which behavioural norms needed to be observed. Pyhä was used to gloss territorial boundaries at topographically anomalous sites in the wilderness. For the members of hunting and fishing communities these sites provided a conceptual domain by which they could draw lines of demarcation between the interior and exterior of their area of exploitation. As an appellative designation for a site, the word pyhä also demarcated situations and events for ritual behavior. The basis for assigning pyhä names to topographical locations lies in the vernacular discourse, which distinguishes conceptually between that which belongs to one's own sphere of activity and that which is outside it. At the same time, it also demarcates situations and events which are performed at these locations at various times during the economic year, especially at critical turning points in the calendar. Finally, these names express the norms and sanctions which regulated behaviour at these significant locations. The adjective $p y h a ̈$ was used of places which the linguistic community wanted to demarcate from the rest of the environment as "separate", "marked", "designated", "prohibited", "dangerous". The mythological-religious dimension overlapped seamlessly with the organization and consolidation of living practices in the structures of the community's own economic domain. The same holds true for the semantic contents of the Indo-European terms for "sacred" as well as for god (Fi. jumala), which the early inhabitants of the present-day Finland adopted as part of their vocabulary. The marking of boundaries by words with pyhä did not signify merely a legal ground for the owners - in the early sense, emphasizing collective ownership - but also for the mythological/religious factors through which the sense of community was protected and strengthened. During the prehistoric era, the mythical world was located primarily outside the settlement rather than within it. With the rise of the slash-and-burn system of field clearance and an agriculture based on field cultivation, the mythical worlds of the Finnish peasants began to take shape in terms of the edges and borders of these fields.

Edgar Polomé, a well-known scholar of the Indo-Europeans, points out the structural prerequisites out of which the use of the notion grew: "The 
main point is the emphasis on the contrast inside versus outside which prevails at each level of the social structure and conditions human relations" (Polomé 1982, 161). In considering the transformation of pyhä locations into proper names (toponyms), as well as the adoption of the word into Christian parlance, we have to keep in mind that the pyhä-word was originally used to express precisely the ownership and control of boundary-behavior in the outlying, backwoods wilderness areas. As Christianity became introduced to the Finns, however barbaric early baptized Christians may have been in the $11^{\text {th }}$ and $12^{\text {th }}$ centuries, they contested the locative dimensions of hunters and agriculturalists, who still held the tradition of naming and marking wilderness regions by the term "sacred". Throughout the Middle Ages ordinary lay Christians as well as priests and bishops continued to contest pagan folk traditions and worked to uproot forms of belief and practice such as bear-killing rituals, the choreography of which displayed the sacrality of the bear. The bear was perceived as an anthropomorphic, human-like agent, whose marked position as an embodiment of the boundary line between the village and the forest was expressed in incantations by referring to the animal's mythical origin. ${ }^{4}$

Not only in Finland, but in all the continents of the world, Christianity has remodeled the conceptual contents of the "sacred" as a vernacular notion in cultures where its theological ideas have been disseminated. Remodeling also took place when the Reformation swept over Europe in Late Medieval times. In contesting the antecedent contents of the sacred - whether reformed, non-reformed or restored - theology never concerns itself with the total cultural complex. The fact that theological reason never permeates culture in its entirety can be seen in the flourishing of vernacular forms of religiosity in cultures the world over. The specific nature of theological ideas within the overall conceptual domain of religion is an issue that has been approached from the point of view of cognitive theorizing in recent

\footnotetext{
${ }^{4}$ Lutheran bishop Isak Rothovius, inaugurating the Academy of Turku, in March 1640, tormented the peasant churchgoers for their heathen practices in the sermon: "It is said that, having killed a bear, they hold a feast and drink from the skull of the bear and make sound resembling its growling, in this way wishing to secure themselves successful hunting and rich quarries for the future." (Haavio 1967.) On bear rituals from the point of view of ritual theory, see Smith 1982.
} 
scholarly literature. ${ }^{5}$ Theological systems do not play down to their own, doctrinally constituted conceptual foundation, even though they appear to their believers to be distinct spiritual realities. Members of theological elites share the same social categorizations as the rest of the population and employ them as given conceptual structures both in their work and their daily labors.

\section{Theology, the Female Body and the Ideal of Enclosed Community}

Let me reflect on the use of theological reason in dealing with the notion of women's propriety in their participation in the religious life of the community. ${ }^{6}$ Examples come from my own native country, Finland. After the Reformation that took place in the 1520's, the Evangelical-Lutheran Church continued to apply vernacular social categorizations on physiological states of childbirth and menstruation in judging the propriety of women for social life. It was not only the so-called primitive peoples who categorized women as polluting during periods when their bodily boundaries were open, notably menstruation and childbirth. The means of control by which the domain of religion is kept intact, whether theological or primitive, is intimately connected with the idealization of the body's boundaries. In spite of the fact that all members of the Christian community are theologically considered to be equal in the face of God, theological ideas make a distinction between male and female bodies. The male body is used as a prototype for the enclosed religion, on the cognitive basis of a container metaphor. Image-schemas that structure human cognition, as George Lakoff and Mark Johnson have shown, have a bodily basis, and as such they are inextricable constitutent

\footnotetext{
${ }^{5}$ According to Ilkka Pyysiäinen, "[theological ideas] are brought about by an active inferential or associative process in the mind of the person in question". Contrary to theological ideas, Pyysiäinen posits that the kind of religious ideas that people entertain in the context of everyday practices is "an on-line religion that exists in the inferences, experiences, and actions of interacting individuals. Its opposite is the 'theologically correct' religion which is only a theoretical entity and very difficult to bring to on-line cognition and action." (Pyysiäinen 2004, 157-158.)

${ }^{6}$ My source of inspiration in dealing with the impure, or the left-hand "sacred" is, of course, Mary Douglas 1989 (1966) as well as the French school of the sociology of the sacred, most specifically the work of Robert Hertz and Georges Bataille. Kim Knott has explored the scholarly legacy of the French school in her book The Location of Religion. A Spatial Analysis (2005a). See also Knott in this issue (2005b).
} 
forces of any religious system (see Lakoff \& Johnson 1980; 1999). Theological reason has not broken free from perceiving women's physiological states on the basis of vernacular systems of belief, the roots of which can be reduced to cognitive structures of the human mind. The distinctiveness and conceptual autonomy of the Christian category of the Holy is an idealization and, as such, subject to logics that prevail in vernacular religious systems throughout the world. Theological reason is subject to the predicament of culture. Theology can never separate itself from the soil that the human body provides for its growth, otherwise there is nothing left to transcend. For cognitive reasons, there is no way for theological systems to change the bodily and cultural register on the basis of which socio-religious life is organized. Theological considerations are always selective in placing emphasis on certain social categorizations, leaving others untouched. Christianity, like so many other religious traditions, has a complex cluster of theological concepts that revolve around the notion of God, but no explicit theology of the male and the female body or the notion of boundary that both sets their bodies apart as well as uniting them.

It is we scholars of religion who are doing the hard work of tracking down the mysterious ways in which theological reason, apart from and alongside cultural reason, works (see Sahlins 1976). The fundamental structures in religious data are being explored on the basis of archival sources or of ethnographic accounts and repatriated into the world in which theological reason dominates the discourse of religion. As for women's social and religious propriety, there is a vast array of ethnographic description of rituals in which women are set apart from the social life due to beliefs revolving around the impure states of female physiology and the repercussions of these states on the cosmological boundaries that are supposed to protect the human community. The late stage of pregnancy and menstruation are, thus, perceived as anomalous stages which endanger the conventional boundaries of everyday social life. Bodily openings are connected metonymically to both vertical and horizontal "openings" or "cracks" in the boundaries that are believed to protect and maintain the functionality or plausibility struc- 
ture of a socio-religious community. Notwithstanding the Lutheran view, according to which the conscience of an individual is the prime location of God, women, however, needed to complement pure conscience also with pure body. On closer reflection, theological notions such as "sacred", "grace" and "salvation" are gender-free only as idealizations. Theological notions subsume those general cognitive principles that underlie the human capacity for categorization in which prototype effect, anomaly detection, as well as ideal norms dominate the placement of category boundaries (see Sperber 1996; Anttonen 1999; 2000). The on-going disputes of fundamentalist and liberal theologians over women's ordination in Lutheran Finland, as well as over the rights of same-sex partners to legalize their relationship and/or get married, testify to my theory of "sacred" as a category boundary by which the difference between the domains of the interior and exterior of the space/ territory and the human body are made - as well as being contested. Even though the discourse of the "sacred" may be implicit, the various culture wars that are being fought in the media and in the public sphere attest to the persistence of the "sacred" as a conceptual domain.

\section{Why Does the "Sacred" Matter?}

The category-theoretical approach to religion is a methodological stance that places special emphasis on the value of margins, boundaries, points of crossing, and categorical anomalies as irreplaceable sources of information in an attempt to capture the constitutive factors on which the conceptual foundation of religion, and by the logic of its mother categories, that of individual and society, rests. The "sacred" itself is a category the members of which are all things set apart as sacred, i.e. the specific, value-laden members in the categories of things, objects, times, places, persons, animals and other visible or invisible agents, the special position of which are marked by behavioral rules and restrictions. Regardless of its polysemia, the words and concepts denoting "sacred" form an important arena for scrutiny in the study of religion. I totally disagree with Russell McCutcheon (2001) who denies the significance of the notion as a signpost on the road to understanding "the raw 
materials out of which religions are manufactured" (see Benavides 2000a; 2000b). McCutcheon finds the sacred to be a free-floating signifier that he can't focus on, because it is undefined (McCutcheon 2001, 181). What else is academic scholarship for, if not for finding ways to define that which is un- or ill-defined! With the help of the comparative method, the purpose of the study of religion is to systematize recurrent properties in empirical findings and propose theories to explain their invariance as well as their variance. The boundaries of the "sacred" as a category are, of course fuzzy, but the same also holds true for most categories, for instance the concept of religion. There are no necessary and sufficient conditions by which the category-membership is determined (see Saler 2000). How can a religious studies scholar fail to acknowledge the powerful tradition of research within the fields of anthropology, sociology and history of religion and the unique work of a long line of scholars, particularly William Robertson Smith, James G. Frazer, R. R. Marrett, Émile Durkheim, Sigmund Freud, Henri Hubert, Marcel Mauss, Georges Bataille, Roger Callois, Robert Hertz, Arnold van Gennep, Claude Lévi-Strauss, Mary Douglas, Victor Turner, W. Richard Comstock, Roy Rappaport, Jonathan Z. Smith, William E. Paden, and myself, who have put the notion in perspective with the help of archaeological, linguistic, ethnographic, folkloristic and sociological data. Scholarship on the semantic history and contents of the word and the concept of "sacred" provide an irreplaceable tool to unmask the common cultural as well as cognitive foundations of religion and societies as conceptual entities.

Why then does the issue of sacrality matter? Stewart Guthrie has pointed out in his theory of anthropomorphism and animism as the cognitive origin of religion that human beings possess an agent-detection device (see Guthrie 1995; 2004). But do we also have a sacred-detection device? Evidently we have. The "sacred", however, does not need to be linked directly to the human capacity for agency recognition. The idea of the sacred is founded on our bodily being and the mental representation of interior and exterior spatial coordinates. The word and the concept does not need to have a fixed point (a fixed agent to refer to) which defines its content. Where the attribute 
becomes established and in reference to what depends on the particular conceptual system. Scholars of religion need a theory which addresses local categorizations and explains the properties on the basis of which various sacralities are construed in specific geographical, historical and ideological context. My proposition is to explore the conceptual domain of the notion by beginning from the human capacity for categorization and for investing special significance to categorical boundaries which enable transitions and transformations to occur. This conclusion has also been reached by Jamsheed K. Choksy, who posits that "concepts like purity, holiness, and sacrality are not ontologically separate from the human life. The pure, holy, and sacred can be regarded as conceptual categories that overlap under the metacategory called 'religion', which in turn is part of principles of separation, categorization, abstraction and symbolization" (see Choksy $2003,34)$. The cultural logic by which the attributions of "sacrality" are constituted - whether as a referent to a distinct metaphysical entity or as an ontological level of existence or as an attribute of value - is governed then by the principles of categorization. It is the notion of a category boundary that establishes the "sacred" and the difference that it makes. The "sacred" can be located in reversible category positions, whether in things pure or impure, licit or forbidden (taboo), fixed or unfixed, violable or sacrosanct. The notion of "sacred" - and the act of sacralization - becomes more open to empirical verification when it is theorized on the basis of the actions, events and intentions of cultural agents in specific contexts as they make distinctions between spaces, mark them for specific uses, create visible and invisible boundaries, and establish cultural conventions of behavior to deal with those boundaries. In short, the "sacred" that separates, binds, transcends and purifies, is the location for ritual communication. 
Bibliography

\section{Anttonen, Veikko}

1996 Rethinking the Sacred: The Notions of "Human Body" and "Territory" in Conceptualizing Religion. - Thomas A. Idinopulos \& Edward A. Yonan (eds), The Sacred and Its Scholars: Comparative Methodologies for the Study of Primary Religious Data, 36-64. Leiden: E. J. Brill.

1999 Does the Sacred Make a Difference? Category Formation in Comparative religion. - Tore Ahlbäck (ed.), Approaching Religion, Part I, 9-23. (Scripta Instituti Donneriani, 17:1.) Åbo: The Donner Institute.

2000 Sacred. - Willi Braun \& Russell T. McCutcheon (eds), Guide to the Study of Religion, 271-282. London: Cassell.

\section{Benavides, Gustavo}

2000a Review: Russell T. McCutcheon, Manufacturing Religion: The Discourse on Sui Generis Religion and the Politics of Nostalgia. - Religion 30 (2), 205-208.

2000b What Raw Materials Are Used in the Manufacture of Religion? - Culture and Religion 1, 113-122.

\section{Benveniste, Émile}

1973 Indo-European Language and Society. London: Faber and Faber.

\section{Boyer, Pascal}

2001 Religion Explained: The Evolutionary Origins of Religious Thought. New York: Basic Books.

\section{Choksy, Jamsheed K.}

2003 To Cut Off, Purify, and Make Whole: Historiographical and Ecclesiastical Conceptions of Ritual Space. - Journal of the American Oriental Society 123 (1), 21-41.

\section{Douglas, Mary}

1989 (1966) Purity and Danger. An Analysis of the Concepts of Pollution and Taboo. London: Ark Paperbacks.

\section{Durkheim, Émile}

1995 (1912) The Elementary Forms of Religious Life. A New Translation by K. E. Fields. New York: The Free Press.

\section{Eliade, Mircea}

1959 The Sacred and The Profane. The Nature of Religion. New York: A Harvest Book.

\section{van Gennep, Arnold}

1977 (1911) The Rites of Passage. London: Routledge and Kegan Paul. 


\section{Guthrie, Stewart}

1995 (1993) Faces in the Clouds: A New Theory of Religion. New York: Oxford University Press.

2004 Folk Religion in a Rural Japanese Hamlet: A Fieldwork Perspective. - Temenos 39-40, 101-123.

\section{Haavio, Martti}

1967 Suomalainen mytologia (The Mythology of the Finns). Helsinki: WSOY.

\section{Hubert, Jane}

1998 Sacred Beliefs and Beliefs of Sacredness. - David L. Carmichael \& Jane Hubert \& Brian Reeves \& Audhild Schanche (eds), Sacred Sites, Sacred Places. (One World Archaeology 23), 9-19. London \& New York: Routledge.

\section{Koivulehto, Jorma}

1981 Reflexe des Germ./ $/ \mathrm{e}^{-1} /$ im Finnischen und die Datierung der germanisch-finnischen Lehnwortbeziehungen. - Beiträge zur Geschichte der Deutschen Sprache und Literatur, 333-376.

\section{Knott, Kim}

2005a The Location of Religion. A Spatial Analysis. London: Equinox Publishing.

2005b Spatial Theory and Method for the Study of Religion. - In this volume.

\section{Lakoff, George \& Mark Johnson}

1980 Metaphors We Live By. Chicago and London: University of Chicago Press.

1999 Philosophy in the Flesh: The Embodied Mind and its Challenge to Western Thought. New York: Basic Books.

\section{McCutcheon, Russell T.}

2001 Critics not Caretakers. Redescribing the Public Study of Religion. New York: State University of New York Press.

\section{Polomé, Edgar C.}

1982 Indo-European Culture, with Special Attention to Religion. - Edgar C. Polomé (ed.), The Indo-Europeans in the Fourth and Fifth Millenia, 156-172. Ann Arbor: Karoma Publishers.

\section{Pyysiäinen, Ilkka}

2001 How Religion Works: Towards a New Cognitive Science of Religion. (Cognition \& Culture Book Series, 1.) Leiden: Brill.

2004 Folk Religion and Theological Correctness. - Temenos 39-40, 151165. 


\section{Rappaport, Roy}

1979 Ecology, Meaning, and Religion. Richmond: North Atlantic Books.

Sahlins, Marshall D.

1976 Culture and Practical Reason. Chicago: The University of Chicago Press.

\section{Saler, Benson}

2000 Conceptualizing Religion. Immanent Anthropologists, Transcendent Natives, and Unbound Categories. New York \& Oxford: Berghahn Books.

\section{Smith, Jonathan Z.}

1982 The Bare Facts of Ritual. - Jonathan Z. Smith, Imagining Religion. From Babylon to Jonestown, 53-65. Chicago: The University of Chicago Press.

2004 Relating Religion. Essays in the Study of Religion. Chicago: The University of Chicago Press.

\section{Sperber, Dan}

1996 Why Are Perfect Animals, Hybrids, and Monsters Food for Symbolic Thought? - Method E Theory in the Study of Religion 8 (2), 143-169. 
